\title{
Cardiac and other Presentation and Clinical Outcomes of COVID-19 Pandemic among different ethnic and religious populations in the city of Jerusalem
}

\author{
Elad Asher ${ }^{1}$, Tal Y Samuel ${ }^{1}$, Oren Yagel ${ }^{2}$, Arik Wolak ${ }^{1}$, Rivka Farkash ${ }^{3}$, Ronen Durst ${ }^{2}$, Eli \\ Ben-Chetrit ${ }^{1}$, Yigal Helviz ${ }^{1}$, Ariella Tvito ${ }^{1}$, Ran Nir-Paz ${ }^{2}$, Offer Amir ${ }^{2}$, and Michael \\ Glikson $^{1}$ \\ ${ }^{1}$ Shaare Zedek Medical Center \\ ${ }^{2}$ Hadassah Medical Center \\ ${ }^{3}$ Affiliation not available
}

June 30, 2021

\begin{abstract}
Background: The COVID-19 pandemic is an ongoing global pandemic. Jerusalem with its 919,400 inhabitants has a wide variety of populations, of which $62 \%$ are Jews (36\% ultra-orthodox; $64 \%$ non-ultraorthodox) and $38 \%$ Arabs which were largely affected by the pandemic. The aim of our study was to understand the different presentations, course and clinical outcomes in these different ethnical and cultural groups in Jerusalem in the COVID-19 pandemic. Methods: We performed a cohort study of all COVID-19 patients admitted between March 9 - July 16, 2020 to the two university medical centers in Jerusalem. Patients were divided according to their religion and ethnicity into 3 main groups: 1) Ultra-Orthodox Jews; 2) other (non-Ultra-Orthodox) Jews and 3) Arabs. Results: Six hundred and two patients comprised the study population. Of them the 361 (60\%) were Ultra-Orthodox Jews; 166 (27.5\%) non-Ultra-Orthodox Jews and 75 (12.5\%) Arabs. The Arab patients were younger than the Ultra-Orthodox Jews and the non-Ultra-Orthodox Jews ( $51 \pm 18$ year-old vs. $57 \pm 21$ and $59 \pm 19$, respectively, p $<0.01)$, but suffered from significantly more co-morbidities. Moreover, hemodynamic shock, ischemic ECG changes and pathological chest $\mathrm{x}$-ray were all more frequent in the Ultra-Orthodox patients as compared the other groups of patients. Being an Ultra-Orthodox was independently associated with significantly higher rate of Major Adverse Cardiovascular Events (MACE) [OR=1.96; 95\% CI (1.03-3.71), $\mathrm{p}<0.05]$. Age was the only independent risk factor associated with increased mortality rate [OR=1.10; $95 \% \mathrm{CI}(1.07$ 1.13), $\mathrm{p}<0.001$ ]. Conclusions: The COVID-19 first phase in Jerusalem, affected different ethnical and cultural groups differently, with the Ultra-Orthodox Jews mostly affected by admission rates, presenting symptoms clinical course and MACE (Acute coronary syndrome, shock, cerebrovascular event or venous thromboembolism). It is conceivable that vulnerable populations need special attention and health planning in time of pandemic, to prevent rapid distribution and severe morbidity.
\end{abstract}

\section{Hosted file}

covid-19 Jerusalem.docx available at https://authorea.com/users/407916/articles/528506cardiac-and-other-presentation-and-clinical-outcomes-of-covid-19-pandemic-amongdifferent-ethnic-and-religious-populations-in-the-city-of-jerusalem

\section{Hosted file}

Figure 1.pptx available at https://authorea.com/users/407916/articles/528506-cardiac-andother-presentation-and-clinical-outcomes-of-covid-19-pandemic-among-different-ethnicand-religious-populations-in-the-city-of-jerusalem 


\section{Hosted file}

Figure 2.pptx available at https://authorea.com/users/407916/articles/528506-cardiac-andother-presentation-and-clinical-outcomes-of-covid-19-pandemic-among-different-ethnicand-religious-populations-in-the-city-of-jerusalem

\section{Hosted file}

Figure 3.pptx available at https://authorea.com/users/407916/articles/528506-cardiac-andother-presentation-and-clinical-outcomes-of-covid-19-pandemic-among-different-ethnicand-religious-populations-in-the-city-of-jerusalem

\section{Hosted file}

Table 1.docx available at https://authorea.com/users/407916/articles/528506-cardiac-andother-presentation-and-clinical-outcomes-of-covid-19-pandemic-among-different-ethnicand-religious-populations-in-the-city-of-jerusalem

\section{Hosted file}

Table 2.docx available at https://authorea.com/users/407916/articles/528506-cardiac-andother-presentation-and-clinical-outcomes-of-covid-19-pandemic-among-different-ethnicand-religious-populations-in-the-city-of-jerusalem

\section{Hosted file}

Table 3.docx available at https://authorea.com/users/407916/articles/528506-cardiac-andother-presentation-and-clinical-outcomes-of-covid-19-pandemic-among-different-ethnicand-religious-populations-in-the-city-of-jerusalem

\section{Hosted file}

Table 4.docx available at https://authorea.com/users/407916/articles/528506-cardiac-andother-presentation-and-clinical-outcomes-of-covid-19-pandemic-among-different-ethnicand-religious-populations-in-the-city-of-jerusalem 